\title{
Totuuden kriisin juuret ovat liberalismin kriisissä ja ristiriidoissa
}

\author{
TIMO HARJUNIEMI
}

Teesi totuuden ja faktojen kriisistä on työllistänyt länsimaista älymystöä jo useamman vuoden ajan. Niin tietokirjailijat, journalistit kuin tutkijatkin ovat esittäneet puheenvuoroja totuudenjälkeisestä ajasta, valeuutisista ja pötypuheesta. Vuoden 2016 politiikan megashokit - Trump ja Brexit etunenässä - loivat kyltymättömän kysynnän analyyseille, jotka selittäisivät, miksi keskiluokka hylkäsi demokratian ihanteet ja hyppäsi itsevaltaisiksi luonnehdittujen demagogipoliitikkojen kelkkaan.

Jotain on kiistatta meneillään. Luottamus kansanedustuslaitosta, mediaa ja muita liberaalidemokraattisia instituutioita kohtaan on heikoissa kantimissa eri puolilla läntistä maailmaa. Koronpandemia tuntuu vain kiihdyttävän totuudenjälkeisiä kierroksia: joulukuussa 2020 tehdyn mielipidemittauksen mukaan liki kolmannes saksalaisista aikoo kieltäytyä koronarokotteesta. Kun kattilaan viskataan vielä eliittien pedofiiliringin olemassaolosta fantisoiva Qanon-salaliittoteoria, joka innoitti ainakin joitakuita Donald Trumpin kannattajia rynnimään Yhdysvaltojen kongressiin tämän vuoden tammikuussa, muhennos sakeutuu entisestään.
Kun maailma tuntuu vajoavan vainoharhoihin ja kollektiiviseen alaikäisyyteen, hypoteesi demokraattisten totuus- ja viestintäihanteiden rämettymisestä vahvistuu. Moni arvioi, että entistä monimuotoisempi mediaympäristö, jossa julkista keskustelua moderoivien journalistien valta on heikentynyt, altistaa ihmiset valeuutisten kaltaisille sepitteille. Niitä tehtaillaan joko poliittisista syistä tai internetin kyltymättömään klikkinieluun lapioitavaksi sisältörehuksi. Toiset ovat huolissaan siitä, että valeuutisointia harjoittavat vieraiden valtioiden botit tai trolliarmeijat, jotka pyrkivät kylvämään epäsopua läntiseen arvoyhteisöön.

Huoli valeuutisista niveltyy laajempaan ajatukseen totuudenjälkeisestä ajasta. Totuudenjälkeisellä ajalla viitataan episteemiseen murrokseen, joka haastaa liberaalien yhteiskuntien perinteiset tieto- ja viestintäihanteet. Väite kuuluu, että jaettuja, poliittisen kärhämöinnin ulkopuolella olevia faktoja ei enää ole, kun läpinäkymättömien algoritmien kiihdyttämä somelogiikka ajaa ihmiset salaliittoteorioiden pariin ja samanmielisiin kupliin.

Monien poliitikkojen hyökkäykset valtavirtaista journalismia vastaan heikentävät yhteisen 
tilannekuvan muodostamisen edellytyksiä entisestään. Sen enempää media kuin asiantuntijatkaan eivät näyttäydy objektiivisina yhteisen hyvän vaalijoina, vaan erilaisten poliittisten tai taloudellisten eturyhmien käsikassaroina. Poliittisen vasemmiston ja kriittisten yhteiskuntatieteilijöiden aiemmin hellimät kritiikit ontoksi kovertuneesta ja eliittivetoisesta "post-demokratiasta" (Crouch 2004) valtavirtaistuvat laajaksi epäluulon kulttuuriksi, jossa kaikki valta on läpimätää ja korruptoitunutta.

Nämä huolenaiheet on syytä ottaa vakavasti, eikä niitä tule sivuuttaa silkkana moraalipaniikkina. Vaarana kuitenkin on, että valeuutisten ja totuudenjälkeisyyden kaltaisiin iskusanoihin ihastuva unohtaa, että käsillä oleva tiedollinen kriisi ei kumpua kansalaisten yhtäkkisestä kognitiivisesta taantumuksesta tai sosiaalisen median algoritmeja alati koukuttavammiksi hiovien Piilaakson propellipäiden pahansuopuudesta. Kyse on pikemminkin liberalismin sisäisistä ristiriidoista, jotka oireilevat paitsi poliittisina myös viestintäteknologisina myllerryksinä.

\section{Orgaaninen kriisi}

Poliittisesti liberalismin vakautta horjuttaa jo Antonio Gramscin tunnistama orgaaninen kriisi. Poliittisten yhteenliittymien rakentamisesta on tullut entistä työläämpää. Kun yksituumaisuus ja hallitsevan luokan legitimiteetti alkavat horjua, politiikasta tulee toraisaa ja hankalaa, Gramsci muistuttaa. Totunnaisuudet kyseenalaistetaan, ja seuraava hegemoninen kokoonpano hakee vasta muotoaan.

Gramscilaisesta vinkkelistä on vain luonnollista, että nykypolitiikkaa luonnehtii hajaannus. Perinteiset valtapuolueet rämpivät kannatusalhossa eri puolilla Eurooppaa, kun eritoten uudet laitaoikeistolaiset liikkeet ahmivat keskustaoikeiston ja -vasemmiston kannatusta. Orgaanisen kriisin keskellä politiikan liittoumat ovat hajanaisia ja usein lyhytikäisiä. Päivänpoliittiset repeämät seuraavat toisiaan, ja hallitsijat hoipertelevat vuoron perään vaihtopenkille huilaamaan kuin jääkiekkoilija ronskin taklauksen jäljiltä.
Sekasorron juuret voi paikantaa vuoden 2008 taloussortumaan, jolloin läntisen kapitalismin uusliberaaliksikin nimetty, kasvavassa määrin yksityiseen velkaantumiseen perustunut kasvumalli alkoi savuttaa. Työttömyys ja talouskuri koettelivat eritoten maltillisen vasemmiston kannatusta ja poikivat 1990-lukulaista konsensuspolitiikkaa haastaneita puolueita poliittisen kentän eri laidoille. Kolmannen tien sosialidemokratia pystyi vielä 1990-luvulla ja 2000-luvun alussa sovittelemaan yhteen rahoitusmarkkinoiden ja vakautta kaipaavan äänestäjäkunnan vaatimuksia tekemällä myös työläisistä omistusasujia ja oman elämänsä varainhoitajia. Näin palkkatyöllä elävän äänestäjän odotushorisontti sidottiin osakekursseihin ja euribor-korkoihin. Johtoajatuksena oli, että entistä avoimemmat pääomamarkkinat tarjoaisivat myös duunarille tilaisuuden nauttia asuntojen ja muiden varallisuuserien arvonnoususta. Omistamisen ja vaurauden demokratisoituminen hävittäisi myös luokkakonfliktit, eikä työn ja pääoman välinen ristiriita enää kiinnostaisi muualla kuin historiaan juuttuneissa marxilaisissa lukupiireissä ja muissa perinnejärjestöissä. Resepti tuntui toimivan, kunnes luottolama ja talouskuri muistuttivat materiaalisten ristiriitojen olemassaolosta.

\section{Massojen pelko ja demokratian kritiikki}

Toisaalta totuuden kriisiä luotaavissa analyyseissa tukeudutaan usein 1900-luvun alun viestinnän tutkimusta leimanneisiin oletuksiin joukkoviestinnän tuhoisista vaikutuksista demokratialle. Taloudellisten kriisien ja poliittisten ääriliikkeiden nousun sävyttämä 1900-luvun alku tuokin kiinnostavalla tavalla mieleen nykykeskustelut faktojen hädästä. Tehokkaaksi osoittautunut sotapropaganda, PR-ammattilaisten nousu ja halpojen sanomalehtien skandaalinkäryiset kohu-uutiset nakersivat 1900-luvun alussa uskoa liberaalidemokratian mahdollisuuksiin ja lietsoivat joukkoviestimiä kohtaan koettua epäluuloa. Amerikkalaisen journalismin historian keskeisiin hahmoihin lukeutuva Walter Lippmann (18891974), joka käsitteli laajassa tuotannossaan niin 
demokratiaa kuin julkista mielipidettäkin, arvioi, että valistuneelle julkiselle mielipiteelle rakentuva demokratia on silkka illuusio (esim. Lippmann 1998/1922; 1993/1927). Yhteiskuntien modernisoituessa ja työnjaon eriytyessä hienostunutta asiantuntijuutta vaativiksi tehtäviksi on yksinkertaisesti kohtuutonta olettaa, että ihmisillä olisi syvällistä ymmärrystä heidän välittömän kokemuspiirinsä ulkopuolelle lankeavista asioista. Lippmannin mukaan tilannetta hankaloitti entisestään se, että valtavaksi poliittiseksi voimatekijäksi ja keskeiseksi tiedonvälittäjäksi noussut massamedia palveli pikemminkin omistajiensa taloudellisia intressejä kuin demokraattisia tavoitteita. Joukkotiedotusvälineet lietsoivat ennakkoluuloja ja levittivät paikkansapitävän tiedon sijasta huhuja ja valheita.

Muun muassa Lippmannia lukeneet viestinnän tutkijat Johan Farkas ja Jannick Schou (2019) kirjoittavat kiinnostavasti, että Trumpin ja Brexitin jälkeistä huolta totuuden kohtalosta sävyttää vuosisadan takainen epäluulo massoja kohtaan. Farkas ja Schou analysoivat journalistista ja akateemista puhetta valeuutisista ja totuudenjälkeisyydestä ja väittävät, että valeuutisia tarkastellaan usein eräänlaisena viruksena, joka sairastuttaa poliittisen yhteisön. Tällainen puheenparsi on omiaan sivuuttamaan niin liberalismin poliittisen kriisin kuin yhteiskuntaan keskeisesti kuuluvat vastakkainasettelutkin eräänlaisena populistisena pandemiana. Toimittaja Matti Mörttinen (2020) haaveilikin Ylelle kirjoittamassaan kolumnissa, että kansalaisia voitaisiin suojata rokottein paitsi COVID-19-taudilta myös populismin seireeninlaululta ja valheellisilta lupauksilta.

\section{Liberalismin ja totuuden jännitteinen suhde}

Faktojen arvovallan hapertumista harmiteltaessa unohtuukin helposti, että liberaalien yhteiskuntamallien suhde totuuteen ja asiantuntijatietoon on historiallisesti ollut jännitteinen. Tämä hämärtyy helposti, sillä valeuutiset ja totuudenjälkeisyys määritellään usein nimenomaan liberaaleja viestintäihanteita haastaviksi ilmiöiksi. Liberaalin demokratian keskeisiä periaatteita on, että puolueeton ja vapaa media välittää ihmisille paikkansapitävää tietoa poliittisen päätöksenteon tueksi. Faktojen kiihtyvä politisoituminen ja mediamaiseman myllerrykset koettelevat liberalismin rationalistisia ihanteita ja hierarkkista totuusjärjestystä. Olemme siirtymässä karrikoidun postmoderniin vaihtoehtomaailmaan, jossa kukin voi valita omat faktansa ja kyseenalaistaa vastapuolen asiantuntijat.

Liberalismia voi kuitenkin tarkastella myös vastakkaisesta suunnasta: ideologiana, jonka luontainen logiikka jouduttaa totuuden ja asiantuntijuuden kriisiytymistä. Michel Foucault'n (2008) tunnettu analyysi historiallisesti muuttuvista "totuuden regiimeistä" auttaa ymmärtämään liberalismia rakennelmana, joka nojaa toisaalta markkinoihin ja vapaiden yksilöiden oma-aloitteiseen toimintaan ja toisaalta asiantuntijavetoiseen hallintaan.

Foucault kirjoittaa, että klassinen poliittinen taloustiede alkoi 1700-luvulta alkaen tarkastella markkinoita totuuden tuottamisen mekanismina, jonka käskyihin hallitsijoiden olisi sovitettava toimintansa. Toisaalta teknokraattinen mittaaminen ja ihmiselämän yksityiskohtainen sääntely ovat yhtä lailla kiinteä osa liberaalia elämää. Liberaali yhteiskunta on myös riskien yhteiskunta, jossa vapauden rajoja säännellään yksilöllisen ja yhteisen hyvän nimissä. Vakauden ja ennustettavuuden edellyttämää kuria on liberaaleissa yhteiskunnissa ylläpidetty koulun ja vankilan kaltaisilla instituutioilla sekä asiantuntijuuden erilaisilla muodoilla. Lääkärit, ravintoterapeutit ja taloustieteilijät kertovat, miten yksilöiden ja kansakuntien kannattaisi elää.

Jännite teknokraattisen asiantuntijuuden ja vapaiden markkinoiden välittämän julkisen keskustelun välillä on leimannut myös liberaalia joukkoviestintää, vaikka mediahistoriaa usein luetaankin emansipaatiokertomuksena. Tuttu tarina kertoo, että porvarisluokan nousu 1600- ja 1700-lukujen Euroopassa synnytti Jürgen Habermasin kuvaaman porvarillisen julkisuuden - yksityispiirin ja valtiovallan välisen sfäärin, jossa porvaristo deliberoi yhteisistä asioista järkeään käyttäen. Vähitellen lehdistö vapautui sensuurin ja valtiokontrollin ikeestä ja alkoi näyttäytyä 
liberalismin ihanteiden mukaisena ajatusten vapaana markkinapaikkana. 1800-luvulle tultaessa lehdistö oli vakiintunut merkittäväksi poliittiseksi voimaksi, kaupallisten periaatteiden mukaisesti organisoituneeksi vallan vahtikoiraksi. Liberaaliin eetokseen kuului ajatus, että ideoiden ja mielipiteiden vapaa, markkinaehtoinen kilvoittelu erottelisi totuudet valheista.

1900-luvun alku merkitsi kuitenkin kovaa kolausta laissez-faire-periaatteen mukaisille mediaihanteille. Vapaa kaupallinen media alkoi näyttäytyä pikemminkin liberaalin järjestyksen uhkana kuin sen tukijalkana. Aikansa mediamogulit käyttivät lehdistöarsenaaliaan surutta omien taloudellisten ja poliittisten etujensa pönkittämiseen. Lehtien halpojen irtonumeroiden sivuilla lietsottiin skandaaleja ja hyödynnettiin siekailematta ihmisten ennakkoluuloja ja laajalle levinneitä stereotypioita. Ajatusten vapaa markkinapaikka kaipaisi kipeästi sääntelyä.

Vastaisku seurasi, kun nykyisenkaltainen journalistinen etiikka ja itsesääntely sekä erilaiset viestintäpoliittiset uudistukset alkoivat tuoda liberaaliin viestintämaisemaan järjestystä. Erityisesti Euroopassa valtiot monopolisoivat radiotekniikan mahdollisuudet perustamalla julkisia yleisradioyhtiöitä. BBC perustettiin vuonna 1922 ja Suomen Yleisradio brittiesimerkkinsä innoittamana vuonna 1926. Yleisradiot ottivat tavoitteekseen kansallisen yhtenäisyyden ylläpidon, laajojen kansanjoukkojen sivistämisen ja tasapuolisen tiedonvälityksen. Myös Yhdysvalloissa joukkoviestintää alettiin säännellä entistä pontevammin. Liittovaltio määräsi muun muassa siitä, että tv- ja radiojournalismin oli oltava sisällöllisesti ja poliittisesti tasapuolista.

Journalismi ammattimaistui vähitellen keskiluokkaiseksi professioksi. Se omaksui julkisen palvelun eetoksen ja sitoutui totuudellisuuden ja objektiivisuuden kaltaisiin arvoihin. Näitä arvoja ylläpidettiin muun muassa journalistin ohjeilla, pressiklubeilla ja yliopistollisella toimittajakoulutuksella. Myös sanomalehtien kustantajat olivat valmiita tinkimään voitoistaan ja sitoutumaan vastuullisen tiedonvälityksen periaatteisiin välttääkseen vielä voimallisemman valtiovetoisen sääntelyn. Journalismista kehkeytyi liberaa- lin julkisuuden pelisääntöjä valvoja asiantuntijainstituutio.

Toisen maailmansodan jälkeistä viestinnällistä järjestystä tukivat erilaiset taloudelliset ja poliittiset tukijalat. Ammatillisten periaatteiden noudattamiseen sitoutunut massamedia nautiskeli ensinnäkin yksinoikeudesta laajamittaiseen tiedonvälitykseen, kun teknisiä vaihtoehtoja ei juuri ollut. Median bisnesmalli, jossa lukija- ja katselijajoukkojen huomiota myytiin mainostajille, tiesi tasaista tulovirtaa. Kun talouden pohja oli terve, oli toimituksellisesta autonomiasta kiinni pitäminen vaivatonta. Myös journalismin objektiivisuuden ideologinen perusta oli vahva. Laajan konsensuksen vallitessa journalismi toden totta tuntui riippumattomalta. Länsimaissa historia tuntui saavuttaneen päätöksensä asiantuntijavetoisesti hallinnoidussa markkinataloudessa. Journalismi solahti vaivatta osaksi tätä modernisaatiotarinaa.

Sittemmin tilanne on muuttunut. Kylmän sodan konsensus alkoi purkautua opiskelijaradikalismiin ja kansalaisoikeusliikkeeseen 1960-luvun lopulla. Vietnamin sodan kauhut lietsoivat poliittista kyynisyyttä. Yhdysvalloissa sääntelyvastainen oikeisto alkoi 1970-luvulla haastaa tieteen epäpoliittista auktoriteettiasemaa ja panostaa muun muassa ajatuspajoihin ja omaan mediatoimintaan. Mediakilpailun räjähdysmäinen kasvu ja journalismin portinvartija-aseman katoaminen ovat hankaloittaneet tilannetta entisestään. Ajankäyttömarkkinoilla kilpailu on veristä, ja journalismin on oltava hyvää sisältöä siinä kuin muidenkin mediasisältöjen. Palomuurit, joilla journalistinen päätösvalta on perinteisesti eristetty mediatalojen tulostavoitteista, ovat kovilla. Laajojen yhteiskunnallisten konsensusten mureneminen johtaa mediankulutuksen poliittiseen eriytymiseen. Tuotteet suunnataan tietyn poliittisen identiteetin omaksuneelle kuluttajasegmentille. Yhdysvaltojen mediamarkkinoiden selvä kahtiajako omiaan kiihkeästi puhutteleviin konservatiivisiin ja liberaaleihin medioihin on tietysti ilmiselvin esimerkki journalismin politisoitumisesta. 


\section{Sosiaalinen media totuudenjälkeisenä instituutiona}

Mediamarkkinoiden historiallisen kehityksen kautta avautuu näkymä liberaalien viestintäihanteiden kaksoisluonteeseen. Jos valtiollisen viestintäpolitiikan tukema journalismi kaitsi 1900-luvun puolivälissä julkista elämää eräänlaisena lippmannilaisena asiantuntijainstituutiona, on mediamarkkinoiden kehitys tuonut viimeistään 1980-luvun jälkeen tuonut mieleen toisen liberaalin älykön, Friedrich Hayekin, ajatukset. Ruotsin keskuspankin "taloustieteen nobelilla" vuonna 1974 palkittu Hayek oli 1900-luvun puolivälissä kiistatta intellektuaalisessa alakynnessä, kun asiantuntijajohtoinen yhteiskunnallinen suunnittelu ja moderni keynesiläinen makrotaloustiede tuntuivat löytäneen ratkaisut kapitalismin ristiriitojen hallintaan. Marginaaliin sysätyt hayekilaiset (uus)liberaalit kuitenkin muistuttivat, että luottamus kaikkivoipaan teknokratiaan kielii vaarallisesta hybriksestä, joka tuhoaa markkinoiden hintasignaalit ja viime kädessä jopa vapaan yhteiskunnan, Asiantuntijat eivät, Hayek (1945) kritikoi, pysty käsittelemään markkinoiden loputonta viestitulvaa samalla tavalla kuin markkinoiden informaatioprosessori.

Viestintämarkkinat ovat viimeisten vuosikymmenten aikana siirtyneet monta piirua hayekilaisempaan suuntaan. Viestintämarkkinoiden sääntelyä ja julkisia tiedonvälitysmonopoleja on purettu markkinaehtoisuuden lisäämiseksi. Valvonnasta ja holhoamisesta riisutut viestintämarkkinat välittävät ihmisten toiveita ja haluja todenmukaisemmin kuin elitististen sivistysperiaatteiden ympärille rakentunut joukkoviestintäjärjestelmä, perustelu kuuluu. Yhdysvalloissa esimerkiksi tv-uutisjournalismilta tasapuolisuutta edellyttävä säännöstö on romutettu kilpailun lisäämisen nimissä, mikä on osaltaan vauhdittanut journalismin, politiikan ja talouden kiihkeää yhteenkietoutumista.

Sosiaalinen media on tietysti tyystin oma lukunsa. Siinä missä erilaisia näkemyksiä yhteen kokoavaa journalismia voi - usein kritisoidusta konfliktihakuisuudestaan huolimatta - tarkastella konsensuksen tekniikkana, sosiaalinen media tuottaa pikemminkin kaaosta ja epäjärjestystä. Vaikka mediasyklit ovat kiihtyneet, journalismin toimintaa sääntelevät vakiintuneet ammatilliset käytännöt. Sosiaalinen media disruptoi journalistiset rakenteet ja muokkaa viesteistä viraali-ilmiöitä niiden kiinnostavuuden, ärsyttävyyden tai shokeeraavuuden perusteella. Journalismin ammatilliset rutiinit luovat julkiseen keskusteluun aikatauluja, viiveitä ja järjestystä, mutta sosiaalinen media kanavoi mediakuluttajien päätöksiä liki reaaliajassa.

Sosiologi William Davies (2019) tarkasteleekin sosiaalista mediaa totuudenjälkeisenä instituutiona. Kyse ei ole vihamielisten vierasvaltioiden boteista tai ratkaisuhakuisen keskustelukulttuurin rämettymisestä vaan perinpohjaisen liberaalista logiikasta, jossa yksi viestintäjärjestys on korvattu toisella. Hayekilainen media-arkemme ei koostu sanomalehden kaltaisista kootuista sisältökokonaisuuksista, vaan erilaisista informaatioriekaleista, jotka päätyvät syötteisiimme paitsi omien päätöstemme myös algoritmisten valintojen seurauksena.

\section{Kansallistetaan Facebook?}

On siis selvää, että nykyisessä mediatodellisuudessa on aitoja ja merkittäviä kipukohtia. Ammattimaisen journalismin toimintaedellytysten surkastuminen sekä Facebookin, Googlen ja Twitterin kaltaisten sisältöhirmujen valta-asema herättävät kivuliaita kysymyksiä demokraattisen julkisen keskustelun mahdollisuuksista ja pelisäännöistä. Viestinnän tutkijat Nick Couldry ja Ulises A. Mejias (2019) kirjoittavat datateollisuudesta eräänlaisena kolonialismin muotona, joka ulottaa datankeruun sosiaalisen toiminnan keskeiseksi periaatteeksi. Couldryn ja Mejiaksen teesin valossa dataa kerääville alustoille keskittyvää sosiaalista elämää ei tulisi tarkastella niinkään politiikan julkisuuden areenana kuin - politiikan filosofin Jodi Deanin (2018) termein -"kommunikatiivisena kapitalismina", jossa erilaiset viestinnät muodot ovat entistä merkittävämpi lisäarvon lähde. Digialustat lupaavat poliittisen vaikuttamisen mahdollisuuksia ja madaltuneita viestintähierarkioita sitouttaakseen käyttäjänsä palkattomaan sisällön- 
tuotantoon ja algoritmisella varmuudella toistuviin mikrokohuihin. Toimittaja ja tietokirjailija Richard Seymour (2019) kirjoittaakin sosiaalisen median tekevän käyttäjistään addikteja tai impulsiivisia trolleja, joita ajaa eteenpäin somevastustajan nöyryyttämisestä uutettu nautinto.

On siis varsin perusteltua pohtia, miten nykyisen mediamaailman piirteet vaikuttavat politiikan julkisuuteen. Tiedon välittäminen ja poliittisen keskustelun ylläpito ovat median tutut liberaalidemokraattiset tehtävät, mutta sosiaalisen median alustat on viritetty palvelemaan toisenlaisia tavoitteita. Moni juhli Twitterin taannoista päätöstä sulkea Donald Trumpin tili säällisyyden riemuvoittona, vaikka Trumpin estottomasta viserrystyylistä hyötyneen Twitterin sulkupäätöstä voi tarkastella myös silkkana opportunismina tai viileänä riskienhallintana. Yhtä kaikki päätös osoitti, millaista sosiaalisen median alustojen valta voi raadollisimmillaan olla ja miten läpinäkymättömästi tuota valtaa käytetään.

Mikä sitten neuvoksi? Voi olla, että viestinnällinen heiluri on jälleen liikkeellä ja digialustojen sääntely kiristyy. Somejättien lisäsääntelyn tarpeesta vallitsee laaja poliittinen konsensus, ja radikaalia sääntelyä pelkäävät yritykset ovat valmiita monenlaisiin myönnytyksiin, esimerkiksi nykyistä kattavampaan algoritmiseen faktantarkastukseen, vihapuhetta kaitseviin teknisiin justeerauksiin tai kulloinkin "ongelmallisiksi" määriteltävien käyttäjätilien jäädyttämiseen ja sulkemiseen.

Reformien on kuitenkin oltava perustavampia. Julkisin varoin ylläpidetty sosiaalisen median alusta voisi kenties rakentaa toisenlaista kanssakäymisen kulttuuria kuin Piilaakson jätit. Viestinnän poliittista potentiaalia ei ole pakko alistaa koukuttavan kohukoneen logiikalle, vaan verkkoviestinnän tekninen arkkitehtuuri on mahdollista suunnitella myös toisenlaista kanssakäymistä silmällä pitäen. Sosiaalinen media on verraton poliittisen vaikuttamisen, ilonpidon ja tiedonhankinnan väline. Some luo syrjään sysätyille mahdollisuuksia omien vastajulkisuuksien perustamiseen ja vallanpitäjien haastamiseen. Kaupallisen nykysomen toksiset, jatkuvaan reagointiin usuttavat kannustinjärjestelmät tykkäysnappei- neen ja vihanaamoineen ovat kuitenkin myrkkyä avoimelle, mukaan ottavalle ja lipsahduksetkin sallivalle poliittiselle keskustelukulttuurille.

Siltä varalta, että ajatus Facebookin kansallistamisesta tai julkisin varoin rahoitetusta yleissomesta tuntuu hyhmäiseltä, käden ulottuvilla on myös maltillisempia kilpailu- ja viestintäpoliittisia reformeja. Monopolilainsäädäntö tarjoaa työkaluja vaikutusvaltaisimpien mediaryppäiden hajottamiseen. Yhdysvaltain liittovaltion kilpailuviranomainen haastoi Facebookin viime joulukuussa oikeuteen hallitsevan markkina-aseman hyväksikäytöstä ja kilpailun tukahduttamisesta. Liittovaltion jättämän kanteen mukaan Facebook pyrki pönkittämään monopoliasemaansa ostamalla vuonna 2012 Instagramin ja vuonna 2014 WhatsAppin.

Ja aivan kuten sosiaalidemokraattisessa viestintäpolitiikassa on perinteisesti tuettu kulttuuri- ja poliittista journalismia verovaroin, sosiaalisen median yrityksiä ja muita ulkoistetulla sisällöntuotannolla rikastuvia datarohmuja voisi yksinkertaisesti verottaa nykyistä ankarammin. Australia on kaavaillut jo pitkään lakia, joka kanavoisi osan some- ja datayhtiöiden tuloksesta tiedotusvälineille, jotka tuottavat suuren osan somen aikajanoilla jaettavista mediasisällöistä. Vaarana toki on, että näin päädytään tukemaan perinteisiä mediajättejä, jotka voivat olla aivan yhtä karmivia kuin nuorekkaammat kalifornialaiset serkkunsa, mutta esimerkkinä tapaus on tärkeä: someyritysten tuloksesta on mahdollista vuolla rahaa erilaisten viestintä- ja journalististen projektien tukemiseen jo hyvin pienillä uudistuksilla. Digihirviöt voivat välillä tuntua kaikkivoivilta, mutta poliittiset työkalut niiden kurittamiseen saattavat löytyä yllättävän läheltä.

VTT TIMO HARJUNIEMI on tutkijatohtori Helsingin yliopistossa. 


\section{KIRJALLISUUS}

Couldry, Nick and Ulises A. Mejias (2019) The Costs of Connection: How Data is Colonizing Human Life and Appropriating it for Capitalism. Stanford: Stanford University Press.

Crouch, Colin (2004) Post-Democracy. Cambridge: Polity.

Davies, William (2019) Nervous States: How Feeling Took Over the World. Lontoo: Vintage.

Dean, Jodie (2018) Crowds and Party. London: Verso.

Farkas, Johan and Jannick Schou (2019) Post-truth, Fake News and Democracy: Mapping the Politics of Falsehood. Abingdon: Routledge.

Foucault, Michel (2008) The Birth of Biopolitics. Lectures at the Collège de France. New York: Picador.

Hayek, Friedrich A. (1945) 'The Use of Knowledge in Society'. The American Economic Review 35 (4): 519-530.

Lippmann, Walter (1998/1922) Public Opinion. New Brunswick: Transaction Publishers.

Lippmann, Walter (1993/1927) The Phantom Public. New Brunswick: Transaction Publishers.

Mörttinen, Matti (2020) “Matti Mörttisen kolumni: Olisipa myös populismia vastaan keksitty rokote” Viitattu 22.3. https://yle.fi/uutiset/3-11678880

Seymour, Richard (2019) The Twittering Machine. London: The Indigo Press. 